\title{
Sosialisasi Thalassemia Kepada Guru Biologi di Banyumas: Upaya Pencegahan Terintegrasi Melalui Kurikulum Sekolah
}

\author{
Lantip Rujito ${ }^{1}$, Diyah Woro Dwi Lestari², Abdul Aziz ${ }^{3}$, Dinar Faiza ${ }^{4}$ \\ 1,2 Universitas Jenderal Soedirman, ${ }^{3}$ Yayasan Thalassemia Indonesia, ${ }^{4}$ Universitas Nahdlatul Ulama Purwokerto
}

\begin{tabular}{|c|c|}
\hline ARTICLE INFO & ABSTRACT \\
\hline $\begin{array}{l}\text { Article History: } \\
\text { Received 24.04.2018 } \\
\text { Received in revised } \\
\text { form 02.06.2018 } \\
\text { Accepted } 26.06 .2018 \\
\text { Available online } \\
\text { 30.06.2018 }\end{array}$ & $\begin{array}{l}\text { Thalassemia is a hematologic disease that causes hemoglobin blood defects. As a } \\
\text { result, red blood cells become fragile and unable to perform their standard } \\
\text { functions. Thalassemia in Indonesia is a quite lot. Recorded data, the carrier traits } \\
\text { are about } 3-10 \% \text {, spread across all provinces. Currently, no final treatment can } \\
\text { cure this disease altogether. Regular transfusion and iron chelating drugs are still } \\
\text { survival of thalassemia patients. Prevention program is one of efficient handling. } \\
\text { The pattern of thalassemia gene decline follows the laws of the recessive Mendel. } \\
\text { Prevention is done by campaigning premarital screening to married couples or } \\
\text { further to younger individuals so they can plan marriages wisely. High School } \\
\text { Biology teachers are an essential factor in preventing thalassemia. They can } \\
\text { deliver prevention programs through lessons at school. They can also be pioneers } \\
\text { in an early self-detection carrier to teenagers before they plan a marriage. Because } \\
\text { of its strategic role, the socialization of thalassemia in high school teachers } \\
\text { becomes very important. }\end{array}$ \\
\hline
\end{tabular}

Keywords: Biology Teacher, Early Prevention, Premarital Screening, Thalassemia.

DOI: $10.30653 / 002.201831 .35$

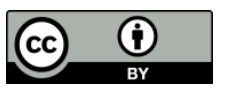

This is an open access article distributed under the terms of the Creative Commons Attribution 4.0 International License, which permits unrestricted use, distribution, and reproduction in any medium, provided the original work is properly cited. ๑ 2018 Lantip Rujito, Diyah Woro Dwi Lestari, Abdul Aziz, Dinar Faiza.

\section{PENDAHULUAN}

Thalassemia adalah penyakit keturunan yang mengenai sistem darah, sehingga tubuh tidak mampu memproduksi hemoglobin secara normal. Secara umum, penyakit ini terjadi akibat mutasi gen alfa atau gen beta yang menyandi protein membentuk susunan hemoglobin darah. Endemisitas pasien-pasien thalassemia terdapat pada daerah yang disebut dengan sabuk thalassemia, dimana Indonesia menjadi salah satu bagiannya. Jumlah penyakit ini meningkat secara signifikan dari tahun ke tahun. Yayasan Thalasssemia Indonesia mencatat bahwa terdapat 8011 pasien per Mei 2017. Namun dengan melihat prevalensi pembawa sifat 3-10\%, dan angka kelahiran 23 per 1.000 dari 240 juta penduduk Indonesia, maka diperkirakan ada sekitar 3.000 bayi 
penderita thalasemia yang lahir tiap tahun (Kementerian Kesehatan Republik Indonesia, 2010). Jumlah ini terbilang kecil dari ukuran jumlah, namun menempati urutan empat teratas dalam klaim BPJS. BPSJ menyebut bahwa thalassemia adalah salah satu dari tujuh penyakit katastropik yang menyedot dana BPJS pada urutan tertinggi. Angka ini dipastikan akan meningkat eksponensial pada tahun-tahun mendatang disebabkan oleh karena thalassemia adalah penyakit yang yang harus mendapat perawatan sejak usia awal kehidupan. Menjadi ironi karena sebenarnya penyakit ini dapat dicegah dan dikendalikan dengan program deteksi dini pembawa sifat atau karier dan konseling genetik pada individu sebelum menikah.

Banyumas adalah salah satu pusat penanganan thalassemia Jawa Tengah bagian selatan sejak 2009. Angka pasien meningkat tajam dari jumlah 60 orang tahun 2010 menjadi kurang lebih 450 pada tahun 2017 atau meningkat hampir 600\% (Hapsari \& Rujito, 2015). Yayasan thalassemia Indonesia cabang Banyumas berupaya melakukan serangkaian program pencegahan thalassemia di wilayahnya dengan program endorsment kebijakan kepada pemerintah daerah, edukasi massal, penyebaran brosur dan media belajar, serta pelatihan-pelatihan kader kesehatan. Salah satu bagian program edukasi massal adalah mengupayakan agar materi tentang thalassemia terintegrasikan dalam kurikulum di sekolah-sekolah. Pintu masuk pembelajaran thalassemia adalah pada mata pelajaran Biologi pada konsep gen dan penurunan sifat. Diharapkan dengan sosialisasi pada guru mata pelajaran Biologi ini, upaya sosialisasi thalassemia pada masyarakat luas dapat berjalan dengan efektif.

\section{METODE PELAKSANAAN}

Sosialisasi ini dilaksanakan dengan metode ceramah dan tanya jawab, serta memberikan stimulasi psikologi kepada para peserta untuk ikut serta terlibat dalam upaya pencegahan thalassemia di Banyumas. Acara diselenggarakan pada hari Jumat tanggal 20 April 2018 bertempat di SMAN 1 Sokaraja. Tim thalassemia terdiri atas konselor genetik, psikolog, orang tua pasien thaalassemia, dan unsur Palang Merah Indonesia (PMI). Peserta adalah seluruh guru SMA mata pelajaran Biologi se-Banyumas berjumlah sekitar 60 perwakilan. Konselor genetik memberikan pengetahuan dasar thalassemia, aspek klinik, dampak sosial, dan upaya pencegahan. Psikolog memberikan pengetahuan tentang aspek psikologi pada anak-anak thalassemia. Orang tua pasien memberikan testimoni tentang bagaimana mengelola anak dengan thalassemia sedangkan unsur PMI memberikan motivasi mengenai donor darah sebagai salah satu kebutuhan penting pengelolaan pasien thalassemia.

\section{HASIL DAN PEMBAHASAN}

Sosialisasi diawali dengan memberikan definisi dan aspek klinis thalassemia. Thalassemia adalah penyakit genetik, tidak menular, yang diturunkan oleh kedua orang tua pembawa gen mutan thalassemia kepada anaknya. Anak dengan thalassemia akan mengalami kelainan hemoglobin darah, dimana tubuhnya tidak mampu memproduksi komponen hemoglobin yaitu rantai alfa atau rantai beta. Akibatnya tubuh akan mengalami gangguan sistemik akibat ketidakmampuan darah dalam mendistribusikan oksigen ke seluruh tubuh (Higgs, Engel, \& Stamatoyannopoulos, 2012).

Kondisi thalassemia dibedakan atas tiga kategori klinik utama, yaitu thalassemia minor, intermedia, dan mayor. Thalassemia minor nama lainnya adalah pembawa sifat 
atau karier thalassemia. Individu ini tidak akan menunjukkan gejala klinis, bahkan dalam beberapa kasus mereka adalah orang-orang yang berdonor darah. Individu minor tidak bisa dikenali karena terlihat sehat. Pemeriksaan laboratorium darah diperlukan untuk mengetahui apakah orang yang nampak sehat tersebut adalah karier atau tidak. Individuindividu karier inilah yang akan menurunkan gen mutan thalassemia kepada anakanaknya. Kategori kedua adalah thalassemia intermedia. Kategori ini adalah individu thalassemia yang mengandung mutan dari kedua orang tuanya akan tetapi jenis mutannya adalah jenis kelainan yang ringan. Individu yang membawa sifat mutan intermedia ini memerlukan transfusi darah akan tetapi tidak rutin, kadang ada yang harus transfusi 3 bulan sekali, 6 bulan sekali atau bahkan 1 tahun sekali. Kategori mayor adalah kategori mudah dapat terlihat karena menunjukkan gejala anemia, pucat sejak usia awal tahun. Usia awal mengalami kelainan klinik adalah usia 6 bulan sampai 1 tahun, waktu dimana terjadi pergantian hemoglobin dari $\mathrm{Hb}$ fetus $\mathrm{ke} \mathrm{Hb} \mathrm{A}$ atau dewasa. Anak dengan thalassemia mayor akan membutuhkan penanganan berupa transfusi rutin setiap 2-4 minggu sekali dari usia diagnosis sampai sepanjang hidup mereka. Beberapa mutan pada gen modifier dapat mempengaruhi ketiga kategori yang umum ini (Rujito et al, 2016). Akibat transfusi rutin mereka harus mengkonsumsi obat kelasi besi secara rutin untuk mengeluarkan besi yang menumpuk pada sistem organ mereka. Individu mayor juga harus mengkonsumsi sejumlah vitamin untuk membantu proses pembentukan sel darah merah (Greene, 2014).

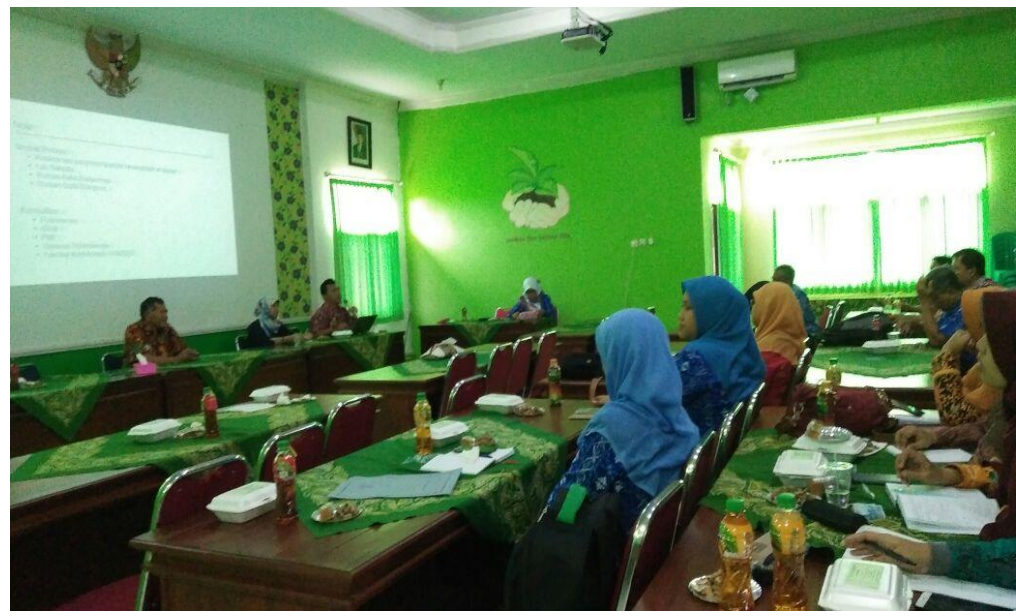

Gambar 1. Konselor Memberikan Edukasi Kepada Para Guru SMA Biologi

Pada aspek pencegahan, konselor menjelaskan tentang pentingnya memberikan pengetahuan aspek penurunan gen mutan pada individu mayor. Bahwa penyakit thalassemia akan timbul jika 2 gen mutan bertemu pada satu individu, maka perlu diberi penekanan bagaimana agar 2 gen mutan tersebut 'tidak menimpa' pada anak. Kondisi thalassemia mayor mengikuti hukum mendel pada penurunan sifat resesif, yaitu jika ada gen mutan pada kedua orang tuanya, maka kemungkinan terjadinya anak mayor adalah $25 \%$, anak pembawa sifat $50 \%$, dan anak sehat $25 \%$. Peluang ini terjadi pada setiap kelahiran anak. Hal ini kadang disalahartikan, seperti bahwa jika anak pertama lahir dengan thalasemia mayor maka anak kedua dan seterusnya akan sehat atau pembawa. Maka dapat ditemui di masyarakat kita, orang tua dengan 2-4 anaknya thalassemia mayor semua (Cao \& Kan, 2013).

Pada negara dengan prevalensi thalassemia yang tinggi, pre-marital skrining menjadi suatu cara yang handal dalam mencegah laju pertumbuhan thalassemia. Negara 
Cyprus, Iran dan Mediterania lainnya sudah lama mencanangkan program ini. Hasilnya angka pertumbuhan anak thalassemia mayor mendekati $0 \%$. Dalam sesi diskusi pertanyaan-pertanyaan yang muncul antara lain: Apakah memungkinkan pencegahan lain seperti dengan bayi tabung dilakukan jika kedua pasangan yang diketahui positif karier kemudian memutuskan untuk menikah? atau pertanyaan bagaimana kalau sudah terlanjut ingin menikah dan ternyata hasil test karier nya positif apa yang harus dilakukan?. Dijelaskan bahwa pencegahan bayi tabung istilah yang lebih tepat adalah PGD atau Preimplantation Genetic Diagnosis atau mendiagnosa penyakit sebelum janin ditanam dalam rahim. Teknik ini memungkinkan secara operasional akan tetapi tidak cost benefit jika dilakukan secara massal. Untuk proses inseminasi diperlukan dana kurang lebih 20-30 juta rupiah, belum lagi biaya untuk mengetes DNA janinnya, tentu akan membutuhkan tambahan biaya yang besar pula, dengan angka keberhasilan yang tidak $100 \%$. Testing lain yang bisa dikerjakan adalah prenatal diagnosis yaitu dengan mengambil sel-sel janin usia 6-9 minggu yang sudah tumbuh di rahim untuk kemudian dilakukan testing DNA. Masalahnya adalah aborsi bayi yang diketahui memiliki kelainan thalassemia mayor di Indonesia belum jelas regulasinya. Selain itu di Indonesia prenatal testing ini belum menjadi tindakan rutin, dan hanya satu dua RS saja yang bisa melakukan. Tentu hal ini akan membawa dilema bagi dokter maupun pasangan itu sendiri.

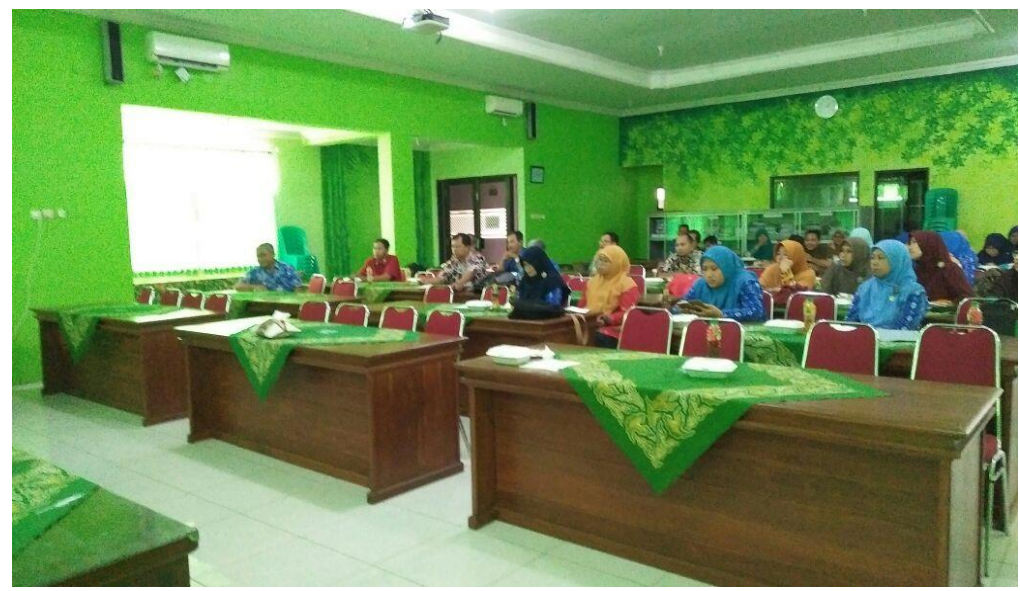

Gambar 2. Para Guru Biologi SMA Mendengarkan Seksama Penjelasan dari Para Pemateri

Untuk pertanyaan kedua tentang hasil positif sebelum menikah apa yang bisa dilakukan? Tim menyampaikan bahwa itu tergantung posisi usia waktu dilakukan skrining tersebut. Jika dilakukan test skrining waktu masih remaja atau dewasa awal sebelum merencanakan pernikahan akan lebih baik. Individu positif tersebut disarankan ketika mencari pasangan seyogyanya memberi penjelasan kepada pasangannya untuk melakukan skrining thalassemia. Jika hasilnya negatif, tentu pasangan 'positif' dan ' negatif' tersebut dapat melanjutkan ke jenjang pernikahan. Jika 'negatif' semua tentu akan aman juga melanjutkan ke tahap pernikahan. Jika diketahui keduanya 'positif' membawa gen mutan, perpisahan akan menjadi jalan 'lebih baik' bagi pasangan tersebut. Namun jika secara sadar individu-individu positif tersebut tetap menikah maka pasangan dapat melakukan prosedur prenatal diagnosis, atau melakukan adopsi anak dikemudian hari, atau secara sadar akan menerima keadaan anak apa adanya (Kementerian Kesehatan Republik Indonesia, 2010).

Terkait dengan tinjauan dari aspek psikologis para individu dengan thalasemia, dijelaskan mengenai kondisi emosi dan mental individu dengan thalasemia. Kondisi 
kesakitan mereka yang mengharuskan perawatan sejak dini membuat individu dengan thalasemia mempunyai kondisi emosi yang berbeda dengan anak normal lainnya. Terapi transfusi yang harus dilakukan secara rutin serta kewajiban melakukan terapi kelasi membuat aktivitas beberapa anak dengan thalasemia menjadi terganggu. Kondisi ini dimungkinkan menjadi anak dengan thalasemia kurang percaya diri serta menganggap diri sebagai individu yang sakit, sehingga diperlukan penguatan berupa motivasi kepada mereka. Hal lain yang dirasa kurang mendukung dalam perkembangan psikologis anak anak dengan thalasemia adalah pengasuhan yang dilakukan di rumah maupun perlakuan yang diterima anak anak dengan thalasemia di sekolah. Kondisi "memanjakan", "mengistimewakan" misalnya dengan tidak melibatkan anak anak dengan thalasemia dalam kegiatan sekolah sama seperti anak yang lain. Kondisi seperti "melabel" anak-anak dengan thalasemia sebagai anak "sakit" dan "tidak berdaya" perlu untuk dieliminir sehingga perkembangan mentalnya dapat berlangsung seperti yang diharapkan. Untuk itu diperlukan kerjasama yang baik antara pihak orang tua, guru dan sekolah serta pihak tenaga medis agar anak anak dengan thalasemia dapat mengembangkan potensinya secara maksimal.

Dari sisi orangtua dijelaskan tentang suka dan duka merawat anak dengan thalassemia. Orang tua harus mengeluarkan biaya yang tidak sedikit untuk mengantarkan mereka transfusi rutin setiap bulan. Belum lagi biaya sosial untuk sekedar "menyenangkan" anak atau agar anak mau mengkonsumsi obat kelasi besi dan vitamin yang jumlahnya bisa sampai 3-10 butir perhari selama hidupnya. Pada umumnya karena saking sayangnya timbul kemanjaan pada anak thalassemia, tetapi tidak semua. Beberapa anak thalassemia dapat berhasil dalam studi, bahkan sampai ke jenjang sarjana dan pascasarjana, dan menjalani hidup selayaknya individu sehat lainnya. Tentu dengan perawatan ekstra ketat dan suport transfusi yang adekuat.

PMI juga menyarankan untuk melibatkan anak anak didik SMA agar mulai ikut terlibat dalam pencegahan thalassemia. Donor darah pada usia anak SMA lanjut dapat memberikan pemahaman tentang hidup empati. Bahwa darah yang mereka donorkan dapat menjadi berguna untuk kehidupan pasien thalassemia sehingga mereka secara tidak langsung termotivasi untuk tidak memiliki anak dengan thalassemia.

\section{SIMPULAN}

Pada akhir sesi, peserta pelatihan berkomitmen untuk ikut serta dalam usaha pencegahan thalassemia dengan memberikan pengetahuan thalassemia pada pelajaran Biologi. Usaha ini diharapkan dapat meningkatkan kesadaran masyarakat mengenai pentingnya deteksi dini karier thalassemia sebelum melakukan pernikahan, sehingga dapat membantu program pencegahan penyakit thalassemia di Banyumas secara khusus dan Indonesia pada umumnya.

\section{REFERENSI}

Cao, A., \& Kan, Y. W. (2013). The prevention of thalassemia. Cold Spring Harbor Perspectives in Medicine, 3(2), 1-16. doi: 10.1101/cshperspect.a011775

Greene, M. (2014). Thalassemia: Causes, Treatment Options and Long-Term Health Outcomes. New York: Nova Science Publishers. 
Hapsari, A. T., \& Rujito, L. (2015). Uji diagnostik indeks darah dan identifikasi molekuler karier talasemia $\beta$ pada pendonor darah di Banyumas. Jurnal Kedokteran Brawijaya, 28(3), 233-237. doi: 10.21776/ub.jkb.2015.028.03.13

Higgs, D. R., Engel, J. D., \& Stamatoyannopoulos, G. (2012). Thalassaemia. The Lancet, 379(9813), 373-383.

Kementerian Kesehatan Republik Indonesia. (2010). Pencegahan Thalassemia (Hasil Kajian Health Technology Assesment tahun 2009). Jakarta: Kemenkes RI.

Rujito, L., Basalamah, M., Siswandari, W., Setyono, J., Wulandari, G., Mulatsih, S., Sofro, A. S. M., Sadewa, A. H. \& Sutaryo, S. (2016). Modifying effect of XmnI, BCL11A, and HBS1L-MYB on clinical appearances: A study on $\beta$-thalassemia and hemoglobin $E / \beta$ thalassemia patients in Indonesia. Hematology/oncology and stem cell therapy, 9(2), 5563. doi: 10.1016/j.hemonc.2016.02.003 